\title{
Pengaruh Kinerja Petugas Rekam Medis Terhadap Keakuratan Pengkodingan Fraktur
}

\section{Effect of Performance Medical Recording Offices on The Accuraty of Fracture Coding}

\author{
Anggia Budiarti ${ }^{1}$, Siska Iskandar ${ }^{2}$ \\ ${ }^{12}$ Sekolah Tinggi Ilmu Kesehatan Sapta Bakti Bengkulu \\ anggiadjonalisman@gmail.com,siska.flonfel@gmail.com \\ Jalan Raflesia, Ratu Agung, Kota Bengkulu
}

\begin{abstract}
ABSTRAK
Rekam medis merupakan berkas yang berisikan informasi identitas pasien, anamnesa, penentuan fisik laboratorium, diagnosa segala pelayanan dan tindakan medik yang diberikan kepada pasien dan pengobatan baik yang dirawat inap, rawat jalan maupun pelayanan gawat darurat. Informasi medis akan digunakan dalam pengkodean ICD-10. Di beberapa rumah sakit di Kota Bengkulu masih minim petugas rekam medis dengan latarbelakang pendidikan Rekam Medis dan Informasi Kesehatan sehingga keakuratan dalam pemberian kode diagnosis merupakan hal yang harus diperhatikan oleh bidang manajemen data klinis, penagihan kembali biaya, beserta hal lain yang berkaitan dalam asuhan dan pelayanan kesehatan. Jenis penelitian adalah kuantitatif dengan design cross sectional untuk melihat pengaruh kinerja kerja petugas rekam medis (pendidikan, pelatihan, lama kerja dan motivasi) terhadap keakuratan dalam pengkodingan fraktur. Hasil penelitian dari 16 responden menunjukkan bahwa pendidikan ( $p$ value $=0,125$ ), pelatihan $(p$ value $=0,758)$ dan lama kerja $(p$ value $=0,300)$ tidak mempengaruhi ketepatan pengkodingan, sedangkan motivasi mempengaruhi ketepatan pengkodingan dengan $p$ value $=0,008$. Motivasi kerja yang berupa reward menimbukan semangat kerja. Dari hasil penelitian tersebut dapat disimpulkan bahwa kinerja petugas rekam medis tidak mempengaruhi keakuratan pengkodingan fraktur.
\end{abstract}

Kata Kunci : Kinerja, Pengkodingan fraktur, Rekam Medis

\begin{abstract}
A medical record is a file containing information on the patient's identity, anamnesis, laboratory physical determination, diagnosis of all medical services and actions given to patients and treatment both inpatient, outpatient and emergency services. Medical information will be used in encoding ICD-10. In some hospitals in the city of Bengkulu, there are still a minimum number of medical record officers with an educational background in Medical Records and Health Information so that the accuracy in providing a diagnosis code is something that must be considered by medical record officers, the accuracy of diagnosis data is very important in the field of clinical data management, cost collection, as well as other aspects related to health care and services. This type of research is quantitative with a cross sectional design to see the effect of work performance of medical record officers (education, training, length of work and motivation) on the accuracy of fracture coding. The results from 16 respondent showed that education ( $p$ value $=0.125)$, training $(p$ value $=0.758)$ and length of work $(p$ value $=0.300$ ) did not affect the accuracy of coding. Meanwhile, motivation affects the accuracy of coding with $p$ value $=0.008$. Work motivation in the form of rewards creates encouragement or morale. From the results of these studies, it can be concluded that the work performance of medical record officers does not affect the accuracy of fracture coding..
\end{abstract}

Keywords: Performance, Fracture coding, Medical Record 
Anggia Budiarti, Siska Iskandar : Pengaruh Kinerja Petugas Rekam Medis .....

\section{PENDAHULUAN}

Peraturan menteri kesehatan No 269/MENKES/PER/2008) pasal (1), menyebutkan rekam medis adalah berkas yang berisikan catatan dan dokumen tentang identitas pasien, pemeriksaan tindakan dan pelayanan lain yang telah diberikan kepada pasien. Rekam medis dapat membantu meningkatkan mutu pelayanan kesehatan berupa pendokumentasian serta pengkodean diagnosis yang akurat, dapat dipercaya, valid dan tepat. Salah satu kompetensi dari rekam medis yang memiliki peran sangat penting dalam meningkatkan mutu pelayanan kesehatan adalah coding (Kementerian Kesehatan Republik Indonesia 2008).

Rohman (2011), menyebutkan bahwa salah satu faktor yang mempengaruhi keakuratan kode diagnosis adalah informasi medis yaitu pengisian kode diagnosis oleh petugas kodefikasi (coder). Pendidikan, pelatihan, lama kerja dan motivasi kerja petugas rekam medis dapat mempengaruhi kelengkapan dan keakuratan data, terutama berkaitan dengan data riwayat penyakit pasien. Pelatihan dan motivasi kerja merupakan masalah yang menimbulkan kendala ketidaklengkapan kode di rumah sakit yang mencerminkan bagaimana rumah sakit mengelola data pasien dengan tepat, cepat dan akurat (Rohman, H., Hariyono 2011). Susanti (2013), menemukan bahwa dari 63,6\% petugas rekam medis memiliki tingkat pendidikan DIII rekam medis dengan masa kerja rata-rata 5,14 tahun dan mempunyai kinerja yang baik sebanyak 63,6\% (Susanti Tentrem 2013).

Fraktur merupakan terputusnya kontinuitas tulang dan ditentukan sesuai jenis dan luasnya. Fraktur terjadi jika tulang mengalami stress yang lebih besar dari yang dapat diabsorbsinya.(Pramono 2012) Di Indonesia, kasus fraktur akibat kecelakaan dari tahun ke tahun semakin meningkat setiap tahunnya berkisar $\pm 1,5$ juta orang. Di provinsi Bengkulu, kasus fraktur terus meningkat setiap tahunnya. Berdasarkan ICD, kodefikasi fraktur wajib menerapkan karakter ke-5 karena menjelaskan jenis fraktur. Apabila tidak dilakukan penerapan karakter ke-5 maka akan terjadi kesalahan kode dan kesalahan dalam pemberian pelayanan kepada pasien (Windari, A. 2016).

Ketidaklengkapan kode fraktur dapat berdampak terhadap pelayanan tindakan medis pada pasien yang tidak sesuai, klaim pembiayaan rumah sakit atau penggantian biaya menjadi tidak sesuai, tidak dapat dijadikan sebagai alat bukti hukum yang sah dan berpengaruh pada pelaporan internal dan eksternal rumah sakit serta secara tidak langsung akan mempengaruhi mutu rumah sakit.(Ni Kadek Lusi 2016). Kinerja petugas rekam medis dipengaruhi oleh faktor internal dan eksternal. Faktor internal antara lain pendidikan, pelatihan, lama kerja dan motivasi. Dengan terbentuknya kinerja pegawai 
yang baik maka diharapkan rumah sakit akan mampu bersaing dengan rumah sakit lain sehingga rumah sakit mampu diakui sebagai rumah sakit yang berkualitas. Survey yang dilakukan di tiga rumah sakit di kota Bengkulu, dari 16 orang tenaga rekam medis, terdapat 6 orang dengan latar belakang pendidikan Non RMIK sehingga ini mempengaruhi petugas dalam melakukan pengkodingan data penyakit pasien. Pendidikan merupakan kunci dalam pengembangan pengetahuan dan kualitas kemampuan seseorang sehingga latar belakang pendidikan dianggap sebagai suatu hal yang sangat penting. Tujuan penelitian ini adalah menganalisis pengaruh kinerja petugas rekam medis terhadap keakuratan pengkodingan fraktur (Susanti Tentrem 2013).

\section{METODE}

Penelitian ini adalah penelitian kuantitatif dengan desain penelitian cross sectional. Penelitian ini dilaksanakan di tiga rumah sakit kota Bengkulu pada bulan Agustus 2020. Populasi dalam penelitian ini adalah seluruh tenaga rekam medis di tiga rumah sakit. Pengambilan sampel dilakukan dengan tehnik total sampling. Variabel independen dalam penelitian ini adalah pendidikan, pelatihan, masa kerja dan motivasi. Variabel dependent penelitian ini adalah keakuratan pengkodingan fraktur. Data dalam penelitian ini menggunakan data primer dan sekunder. Pengumpulan data menggunakan kuesioner dan lembar observasi. Cara analisa data menggunakan analisis univariat dan bivariat (dengan uji Chi-Square). Pengolahan data dengan menggunakan komputer dilakukan beberapa tahap antara lain editing, coding tabulating, entry data, cleaning dan saving.

\section{HASIL}

Hasil analisis univariat bertujuan untuk menggambarkan distribusi frekuensi dari pendidikan, pelatihan, masa kerja, motivasi dan ketepatan koding. Analisis bivariat dilakukan untuk mengetahui pengaruh kinerja petugas rekam medis terhadap keakuratan pengkodingan fraktur. Hasil analisis univariat dapat dilihat pada tabel dibawah ini.

\section{Tabel 1. Distribusi Frekuensi Pendidikan Tenaga Rekam Medis}

\begin{tabular}{ccc}
\hline Variabel & n & \% \\
\hline Pendidikan & 6 & 37,5 \\
Non RMIK & 10 & 62,5 \\
RMIK & 2 & \\
Pelatihan & 14 & 12,5 \\
Non Coding & & 87,5 \\
Coding & 9 & 56,3
\end{tabular}


Anggia Budiarti, Siska Iskandar : Pengaruh Kinerja Petugas Rekam Medis .....

\begin{tabular}{ccc}
\hline Variabel & n & \% \\
\hline$\geq 3$ tahun & 7 & 43,7 \\
\hline Motivasi & 2 & 12,5 \\
Non Reward & 14 & 87,5 \\
Reward & & \\
Pengkodingan & 2 & 12,5 \\
Ketidaktepatan & 14 & 87,5 \\
Pengkodingan & & \\
Ketepatan pengkodingan & &
\end{tabular}

Pada Tabel 1 menunjukkan sebagian besar responden 62,5\% memiliki pendidikan RMIK (Rekam Medis dan Informasi Kesehatan), sebanyak 87,5\% responden telah mengikuti pelatihan coding, sebanyak 56,3\% responden telah bekerja $<3$ tahun, sebagian besar responden bekerja karena motivasi berupa reward $(87,5 \%)$ dan responden melakukan pengkodingan dengan tepat sebanyak 87,5\%.

Tabel 2. Hasil Analisis Pengaruh Kinerja Petugas Rekam Medis (Pendidikan, Pelatihan, Lama Kerja dan Motivasi) terhadap Keakuratan Pengkodingan Fraktur

\begin{tabular}{|c|c|c|c|c|c|c|c|}
\hline \multirow{3}{*}{ Variabel } & \multicolumn{6}{|c|}{ Pengkodingan } & \multirow{3}{*}{$\begin{array}{c}P \\
\text { Value }\end{array}$} \\
\hline & \multicolumn{2}{|c|}{$\begin{array}{c}\text { Ketidaktepatan } \\
\text { pengkodingan }\end{array}$} & \multicolumn{2}{|c|}{$\begin{array}{c}\text { Ketepatan } \\
\text { Pengkodingan }\end{array}$} & \multicolumn{2}{|c|}{ Total } & \\
\hline & $\mathbf{n}$ & $\%$ & $\mathbf{n}$ & $\%$ & $\mathbf{n}$ & $\%$ & \\
\hline \multicolumn{8}{|l|}{ Pendidikan } \\
\hline Non RMIK & 2 & 33,3 & 4 & 66,7 & 6 & 100 & \multirow[t]{2}{*}{0,125} \\
\hline RMIK & 0 & 0 & 10 & 100 & 10 & 100 & \\
\hline \multicolumn{8}{|l|}{ Pelatihan } \\
\hline Non & 0 & 0 & 2 & 100 & 2 & 100 & \multirow{3}{*}{0,758} \\
\hline Coding & 2 & 14,3 & 12 & 85,7 & 14 & 100 & \\
\hline Coding & & & & & & & \\
\hline \multicolumn{8}{|l|}{ Masa Kerja } \\
\hline$<3$ tahun & 2 & 22,2 & 7 & 77,8 & 9 & 100 & \multirow[t]{2}{*}{0,300} \\
\hline$\geq 3$ tahun & 0 & 0 & 7 & 100 & 7 & 100 & \\
\hline \multicolumn{8}{|l|}{ Motivasi } \\
\hline Non & 2 & 100 & 0 & 0 & 2 & 100 & \multirow{3}{*}{0,008} \\
\hline Reward & 0 & 0 & 14 & 100 & 14 & 100 & \\
\hline Reward & & & & & & & \\
\hline
\end{tabular}

keakuratan pengkodingan fraktur. Pada variabel pendidikan diketahui tidak memiliki pengaruh terhadap keakuratan pengkodingan fraktur dengan $p$ value $=0,125$. Untuk pelatihan tidak berpengaruh terhadap keakuratan pengkodingan fraktur dengan $p$ value = 0,758. Pada variabel masa kerja, tidak terdapat pengaruh keakuratan pengkodingan fraktur dengan $p$ value $=0,300$. Akan tetapi terdapat pengaruh antara motivasi berupa reward terhadap keakuratan pengkodingan fraktur dengan $p$ value $=0,008(<0,05)$. 


\section{PEMBAHASAN}

Berdasarkan hasil penelitian di tiga rumah sakit di kota bengkulu, menunjukkan bahwa latar belakang pendidikan, pelatihan, dan lama kerja tidak mempengaruhi ketepatan dalam melakukan pengkodingan pada pasien fraktur. Akan tetapi motivasi berupa reward dapat mempengaruhi ketepatan dalam pengkodingan fraktur. Ketepatan dalam pemberian kode diagnosis merupakan hal yang harus diperhatikan oleh tenaga rekam medis. Dari hasil penelitian diketahui bahwa dari 6 orang tenaga rekam medis yang memiliki latar belakang pendidikan Non Rekam Medik dan Informasi Kesehatan (RMIK), sebanyak 2 orang (33,3\%) memberikan kode diagnosis pada kasus fratur tidak tepat. Hal ini dapat dikarenakan petugas tidak memiliki kompetensi untuk mengkode diagnosis penyakit. Mereka tidak mengetahui cara penggunaan ICD-10 untuk proses pengkodean penyakit. Penelitian yang dilakukan oleh Janah, F.M. (2015) menemukan bahwa keakuratan kode diagnosis yang di kode oleh coder dengan latar belakang pendidikan Non RMIK masih banyak yang tidak akurat, hal ini dikarenakan ketidaktahuan penggunaan ICD, belum terdapatnya SOP yang mengatur tentang pengkodean diagnosis, dan kemampuan petugas dalam mengkode diagnosis didapat hanya dari rutinitas sehari-hari (Janah, Friska M., Ibnu Mardiyoko 2015).

Hal ini juga di dukung oleh penelitian oleh Ardian (2014), mengenai keakuratan diagnosis penyakit berdasarkan ICD-10 yang mana menemukan bahwa terdapat 54,8\% kodefikasi penyakit tidak akurat dikarenakan latar belakang pendidikan Non RMIK. Petugas coder dengan latar belakang pendidikan RMIK sudah mendapatkan pengetahuan secara teori dan praktek mengenai pengkodean diagnosis yang lebih mendalam dibandingkan dengan coder yang berlatar belakang pendidikan Non RMIK.(Ardian 2014)

Menurut Isnaini (2019), penyebab ketidaktepatan kodefikasi berkas rekam medis pasien rawat jalan ialah tidak adanya petugas maupun coder yang berlatar belakang rekam medis, tidak adanya alat bantu kodefikasi berupa ICD-10, dan tidak ada SOP koding yang digunakan sebagai pedoman kerja (Isnaini 2019). Adanya pelatihan coder yang cukup akan memberikan pengaruh terhadap kemampuannya untuk mensintesis sejumlah informasi dan menetapkan kode yang tepat. Selain itu, pengalaman, perhatian dan ketekunan coder juga mempengaruhi akurasi pengkodean (Erawantini, F., \& Nurmawati 2017). Menurut Kimberly dkk (2005) dalam hasil penelitiannya menyebutkan bahwa sumber kesalahan pengkodean dikarenakan pada saat alur pasien dan alur berkas. Sumber kesalahan dalam alur berkas antara lain variasi penulisan diagnosis dalam catatan elektronik maupun manual, pelatihan, pengalaman 
Anggia Budiarti, Siska Iskandar : Pengaruh Kinerja Petugas Rekam Medis .....

coder. Kesalahan dalam pengkodingan terjadi karena kurang telitinya petugas, sehingga perlu dilakukan pelatihan terminologi penyakit (Agiwahyuanto, F., Sari 2019).

Menurut Dearden dalam Widodo (2015) mengungkapkan bahwa pelatihan pada dasarnya meliputi proses belajar mengajar dan latihan bertujuan untuk mencapai tingkat kompetensi tertentu atau efisiensi kerja. Sehingga diharapkan dengan adanya pelatihan mengenai pengkodean diagnosis yang cukup akan memberikan pengaruh terhadap kemampuan untuk memahami sejumlah informasi dan menentukan kode diagnosis yang tepat.(Widodo 2015) Penelitian yang dilakukan Erawantini dan Nurmawati (2017), menemukan bahwa pelatihan pada petugas rekam medis tentang pengelolaan rekam medis di pelayanan kesehatan primer dapat meningkatkan pengetahuan dan keterampilan petugas rekam medis (Erawantini, F., \& Nurmawati 2017).

Masa kerja adalah jangka waktu orang sudah bekerja pada suatu organisasi, lembaga dan sejenisnya. Masa kerja dapat menjadi salah satu indikator tentang kecenderungan para pekerja dalam melaksanakan aktivitas kerjanya. Masa kerja yang dimaksud dalam penelitian ini adalah masa kerja coder yang bertugas mengkode diagnosis penyakit pasien di tiga rumah sakit di Kota Bengkulu. Berdasarkan hasil penelitian terdapat 2 orang $(22,2 \%)$ coder dengan masa kerja $<3$ tahun yang mengkodefikasi kasus fraktur dengan tidak tepat. Menurut Ilyas (2001) dalam Janah (2015), pencapaian kerja yang maksimal adalah efektivitasnya yang mengarah kepada pencapaian target yang berkaitan dengan kuantitas, kualitas dan waktu. Semakin lama kerja pegawai diharapkan kinerja karyawan semakin meningkat (Janah, Friska M., Ibnu Mardiyoko 2015).

Faktor lain yang mempengaruhi kualitas dalam bekerja adalah motivasi. Motivasi merupakan hal yang pernting karena dapat menjadi penyebab, penyalur dan pendukung dari perilaku seseorang yang dapat meningkatkan keinginan untuk bekerja keras dan antusias dalam mencapai hasil yang optimal. Menurut Teori Hierarki Maslow, faktor pendorong yang menyebabkan seseorang mau bekerja ekstra keras adalah motivasi. Motivasi didasari oleh asumsi bahwa seseorang akan bekerja dengan baik bila diberi kesempatan dan dorongan yang tepat (Windari, A. 2016).

Penelitian yang dilakukan oleh Yani (2017), faktor penyebab ketidaktepatan diagnosis fraktur pada pasien rawat inap di RSPAU dr. S. Hardjolukito Yogyakarta di tahun 2017 antara lain man, methode, material, money sehingga ketepatan kode diagnosis fraktur sebesar 43 (62, 42\%) dan pengkodean external causenya belaum terlaksana (Yani 2017) Penelitian ini didukung oleh Ayuningrum (2020), menemukan bahwa jumlah 
petugas rekam medis masih kurang dan ada petugas yang tidak berkualifikasi pendidikan rekam medis, serta ada petugas yang belum mendapatkan pelatihan menyebabkan ketidaksesuai pengkodingan penyakit (Ayuningrum, T. A., Wijayanti, R. A., Deharja, A., \& Santi 2020). Menurut Widayanti (2017), faktor yang mempengaruhi akurasi coding yaitu kelengkapan pengisian formulir resume medis, kemampuan petugas membaca diagnosis, sarana kerja petugas kodefikasi, sarana komunikasi, latar belakang pendidikan dan pelatihan kodefikasi penting untuk ketepatan dalam pengkodean penyakit (Widayanti 2017).

\section{SIMPULAN}

Berdasarkan hasil penelitian dapat disimpulkan bahwa tidak ada pengaruh antara kinerja petugas rekam medis terhadap keakuratan pengkodingan fraktur. Hal ini dapat dilihat dari hasil analisis bivariat yang mana tidak dapat pengaruh antara pendidikan, pelatihan dan masa kerja dengan ketepatan pengkodingan fraktur, akan tetapi terdapat pengaruh antara motivasi berupa reward dengan ketepatan pengkodingan fraktur. Hendaknya pihak rumah sakit memberikan reward kepada petugas rekam medis sebagai salah satu bentuk penghargaan kepada petugas rekam medis dan untuk meningkatkan mutu rumah sakit perlu dilakukan pelatihan terkait pengkodingan terutama bagi petugas dengan latar belakang non RMIK.

\section{UCAPAN TERIMA KASIH}

Penelitian ini banyak pihak yang terlibat sehingga pada kesempatan ini saya mengucapkan terima kasih kepada pihak rumah sakit yang telah memberikan izin peneliti dalam melakukan penelitian di rumah sakit yang dipimpin, serta semua responden yang bersedia terlibat dalam penelitian ini. Sekolah Tinggi Ilmu Kesehatan Sapta Bakti Bengkulu yang telah memberikan bantuan dan dukungan dalam menyelesaikan penelitian ini serta kemenristekdikti yang telah memberikan bantuan material dalam mendukung terlaksananya penelitian ini.

\section{DAFTAR PUSTAKA}

Agiwahyuanto, F., Sari, T. I. Dan Shinta O. 2019. “Analisis Ketepatan Koding Dan Kinerja Petugas Di Unit Koding-Indeksing Rumah Sakit Mitra Husada Kota Pring Sewu.” Manajemen Informasi Kesehatan Indonesia 7.

Ardian, A. 2014. "Keakuratan Kode Diagnosis Penyakit Berdasarkan ICD-10 Di Klinik Praktek Dokter Bersama Lily Yogyakarta.” Tugas Akhir. Yogyakarta: Program Studi D3 Rekam Medis Sekolah Vokasi Universitas Gadjah Mada. 
Ayuningrum, T. A., Wijayanti, R. A., Deharja, A., \& Santi, M. W. 2020. "Pendekatan Sistem Dalam Pengelolaan Rekam Medis Di Rumah Sakit Mitra Sehat Situbondo.” J-REMI: Jurnal Rekam Medik dan Informasi Kesehatan 4.

Erawantini, F., \& Nurmawati, I. 2017. "Pendidikan Dan Pelatihan Pada Petugas Rekam Medis Sebagai Persiapan Menjadi Clinical Instructure (Ci) Di Puskesmas Jelbuk."

Isnaini, V. A. 2019. "Strategi Perbaikan Ketidaktepatan Kodefikasi Berkas Rekam Medis Pasien Rawat Jalan Berdasarkan Icd-10 Dengan Pdca Di Puskesmas Sukodono Lumajang.” In Rmik Politeknik Negeri Jember, Jember.

Janah, Friska M., Ibnu Mardiyoko, dan Dwi Astuti. 2015. "Hubungan Kualifikasi Coder Dengan Keakuratan Kode Diagnosis Rawat Jalan Berdasarkan ICD-10 Di RSPAU Dr. S Hardjolukito Yogyakarta.” Artikel Publish Ilmiah.

Kementerian Kesehatan Republik Indonesia. 2008. Peraturan Menteri Kesehatan Republik Indonesia Nomor 269/Menkes/Per/III/2008 Tentang Rekam Medis. Jakarta.

Ni Kadek Lusi, R. 2016. “Tentang Analisis Ketepatan Pengkodean Diagnosis Berdasarkan ICD-10 Dengan Penerapan Karakter Ke-5 Pada Pasien Fraktur Rawat Jalan Di RSU Mitra Paramedika.”

Pramono, A.E. dan Nuryati. 2012. "Keakuratan Kode Diagnosis Penyakit Berdasarkan ICD-10 Di Puskesmas Gondokusuman II Kota Yogyakarta.” Sekolah Vokasi UGM.

Rohman, H., Hariyono, W. Dan Rosyiah. 2011. "Kebijakan Pengisian Diagnosis Utama Dan Keakuratan Kode Diagnosis Pada Rekam Medis Di Rumah Sakit PKU Muhammadiyah Yogyakarta.” Jurnal Kesmas UAD 5.

Susanti Tentrem. 2013. "Studi Tentang Kinerja Petugas Rekam Medis Di Rumah Sakit Persatuan Djamaah Haji Indonesia. Universitas Muhammadiyah Surakarta."

Widayanti, T. 2017. "Tinjauan Keakuratan Kodefikasi Diagnosis Utama Rawat Inap Kasus Diabetes Mellitus Tahun 2015 Di Rumah Sakit Islam Gondanglegi Malang." Health Care Media 3.

Widodo. 2015. Manajemen Pengembangan Sumber Daya Manusia. Pustaka belajar.

Windari, A., dan Anton Kristijono. 2016. “Analisa Ketepatan Koding Yang Dihasilkan Oleh Koder Di RSUD Ungaran.” Jurnal Risat Kesehatan 5.

Yani, S. J.A. 2017. "Ketepatan Pengodean Diagnosis Kasus Fraktur Pada Pasien Rawat Inap Di RSPAU Dr. S. Hardjolukito Yogyakarta.”

\begin{tabular}{|l|l|}
\hline Submission & 18 September 2020 \\
\hline Review & 23 September - 26 Februari 2021 \\
\hline Accepted & 27 Februari 2021 \\
\hline Publish & 12 April 2021 \\
\hline DOI & $10.29241 /$ jmk.v7i1.557 \\
\hline Sinta Level & 3 (Tiga) Nasional Akreditasi \\
\hline
\end{tabular}

